\title{
Investigating on Protective Effect of Aloe vera Alcoholic Extract Gel on Serum Levels of Interleukin-1, Interferon Gamma and TGF- $\beta$ in Experimental Rat Models with Multiple Sclerosis
}

\author{
Sedigheh Tanoomand ${ }^{1,2}$, Ebrahim Hosseini ${ }^{3}$, Amin Edalatmanesh ${ }^{3}$
}

\begin{abstract}
Introduction: Multiple sclerosis (MS) is a disease of the central nervous system that causes disorders in the nervous system, especially in young people. Increased inflammatory factors are major complications of MS disease. Aloe vera plant has known antioxidant and anti-inflammatory properties. The purpose of this study is to investigate the effect of Aloe vera extract on the serum levels of certain inflammatory cytokines in ethidium bromide (EB)induced MS models in rats.

Methods: In this experimental study, 30 adult female Wistar rats were divided into 6 groups of 5 each, including control, sham, experimental 1 (received $14 \mu \mathrm{l}$ EB solution), and experimental 2, experimental 3 and experimental 4 groups which received EB solution associated with $300,600 \mathrm{and} 1200 \mathrm{mg} / \mathrm{kg}$ Aloe vera alcoholic extract gel, respectively. EB was administered into the lateral ventricles and the extract was given by gavage. On day $35^{\text {th }}$, blood serum levels of TGF- $\beta$, interleukin- 1 and interferon gamma were measured by blood sampling from the animals. The results were analyzed by ANOVA and Duncan tests at $5 \%$ level of significance $(p \leq 0.05)$.

Results: The results showed that EB increased the mean serum concentrations of TGF- $\beta$, interleukin 1 and interferon gamma, while simultaneous administration of EB with $1200 \mathrm{mg} / \mathrm{kg}$ of the Aloe vera alcoholic extract gel significantly reduced the above factors at level of $\mathrm{P} \leq 0.05$ as compared with EB group.

Conclusions: The results of this study showed that the Aloe vera alcoholic extract gel in a dose-dependent manner can reduce EB effects on serum levels of TGF- $\beta$, interleukin-1 and interferon gamma in the rats with MS.
\end{abstract}

Keywords: aloe vera gel, MS, inflammatory factors, rat

\section{INTRODUCTION}

Multiple sclerosis (MS) disease is a central nervous system disorder that followed by disability at nervous system, especially in young people (1), causing some nerve symptoms such as weakness and anorexia in the extremities, visual changes, bladder dysfunction, pain and fatigue (2). Failure to fully understand the nature of the disease has caused no definitive treatment for this condition (3). With a ratio of 1.77 to $1, \mathrm{MS}$ is now universally found to be more prevalent in females than males, and its' maximum age range is between 20 up to 40 years of age. On the other hand, its' clinical process is varied and can be ranged from a completely benign process to a progressive and debilitating process (4). According to Iranian MS society, there are approximately 40,000 patients with MS disease in Iran (5) which account for a large percentage of the population; therefore, study and recognition of the disease can help to a large number of people in the community to improve their symptoms caused by MS. Apart from demyelination, the other symptom of the disease is inflammation (6). Repetitive autoimmune attacks to the central nervous system are responsible for acute inflammatory injury and consequently the inability of people with the disease (3). On the other hand, studies have shown that cytokines play an important role in the pathogenesis of MS and they are a major target for therapeutic interventions (7). As stated,

\footnotetext{
1 Department of Biology, College of Science, Fars Science and Research, Branch, Islamic Azad University, Fars, Iran.

2 Department of Biology, College of science, Shiraz Branch, Islamic Azad University, Shiraz, Iran.

3 Department of Biology, Shiraz Branch, Islamic Azad University, Shiraz, Iran.

Correspondence: Ebrahim Hosseini

Department of Biology, Shiraz Branch, Islamic Azad University, Shiraz, Iran.

E-mail:ebrahim.hosseini@yahoo.com

Received: 2 Mar 2018, Accepted: 23 Apr 2018

(c) 2019 by the authors; licensee Modestum Ltd., UK. This article is an open access article distributed under the terms and conditions of the Creative Commons Attribution License (http://creativecommons.org/licenses/by/4.0/).
}

Electronic Journal of General Medicine 
MS causes inflammation, especially in the nervous system (4). These inflammatory responses are correlated with an upregulation of variety of cytokines in multiple sclerosis lesions (8). Some of the cytokines include gamma interferon (IFN $\gamma$ ), interleukin-1 (IL-1), and transforming growth factor (TGF- $\beta$ ). The mentioned factors cause disability in patients with MS and, in order to treat the disease, suppression of them can have beneficial effects in these patients (9). Today, because of complete failure of MS treatment, attention of researchers is attracted to complementary and traditional medicine and they are trying to use all available capacities to solve this problem. Treatment with alternative medicine or herbal medicine is becoming more and more acceptable day by day, and it is estimated that one in three people will use these treatments for various illnesses in his lifetime (10). On the other hand, the use of complementary medicine in diseases such as Parkinson's, epilepsy and cancer suggests the potential use of this method in MS disease (11).

Ethidium bromide (EB) is a compound used as a toxic substance to simulate the pathophysiological process of neurodegenerative diseases such as multiple sclerosis. Local injection of EB to the central nervous system (CNS) selectively eliminates oligodendrocytes and astrocytes and induces focal demyelination in the CNS (12).

One of the plants used in herbal medicine is Aloe vera. Its' scientific name is Aloe spp and belongs to Liliaceae or the lily family (13). It is a monocot plant, its flowers are massive clusters and it has orange to greenish yellow stem. The flower colors in A. vera species and in A. littoralis species are greenish yellow and reddish orange, respectively. With a similarity to cactus, Aloe vera is a perennial, succulent and fleshy plant with approximately up to 2 meters height. It has Lanceolate, acanaceous and thick leaves without petioles. Sharp thorns are observed on the margins of the leaves. When the thorns located at the edge of the leaves are removed, gel is released from their empty positions. This gel contains all the properties of the plant $(14,15)$. The composition of this plant is included $96 \%$ of the Aloe vera gel, consisting of water and the remaining $4 \%$ containing many substances such as essential amino acids, vitamins, salts, enzymes and glycoproteins, of which 75 types are known. The compounds found in the Aloe vera extract gel contain polysaccharides that can reduce and repair inflammations $(14,15)$. The most important chemical compounds of the plant are polysaccharides, anthraquinones, prostaglandins, phytoestrogens such as beta-sitosterol, cholesterol and fatty acids, including campesterol (16). By decreasing inflammatory cytokines, Aloe vera is stated to be effective in controlling inflammatory responses $(17,18)$. It is also likely that Aloe vera improves the complications of patients with MS by inhibiting interferon gamma, interleukin-1, and transforming growth factor. Therefore, based on the mentioned issues and the harmful effects of MS disease on some inflammatory cytokines, and on the other hand, in order to reduce harmful effects of other chemical medicines for treatment of MS disease, it has tried in this study to use the Aloe vera extract gel to reduce harmful effects of chemical medicines. So, the aim of this study is to investigate the protective effects of the alcoholic extract of the plant on the serum levels of certain inflammatory cytokines in ethidium bromideinduced MS model in adult female rats.

\section{MATERIALS AND METHODS}

A number of 30 adult female Wistar rats weighing 200-250 grams were used in this experimental study. The rats were kept in an animal breeding room for a period of one week to adapt to the environment. The rats were kept throughout the study in a cycle of 12 hours of light and 12 hours of darkness and at ambient temperature of 20 to 25 degrees of centigrade. They had free access to water and food. To induce MS disease and to destruct myelin sheath in this study, a solution of $14 \mu$ l ethidium bromide (Merck, Germany) was administered as dissolved in physiologic serum. The induction of MS in the rats in the experimental groups was performed by surgical procedure using a stereotactic device and Hamilton syringes and 30 needles (19). To prepare the Aloe vera alcoholic extract gel in this study, a number of fresh leaves of the plant were firstly prepared. The leaves were then washed and the gel removed. The gel (equal to four times of the volume) was poured in 95 degrees ethanol. Gel container was placed on a shaker for 4 days and the resultant solution was then filtered. It was concentrated using a rotary evaporator at a temperature adjusted at $45^{\circ} \mathrm{C}$ and dried completely at $40^{\circ} \mathrm{C}$. The resultant product was extracted as a powder (20). When estrous cycle of the rats become synchronized in this study, they were randomly categorized into 6 groups of 5 each, including control (untreated), sham (treated with $14 \mu \mathrm{l}$ of saline associated by ethidium bromide solvent using Hamilton syringe to the ventricle lateral), experimental 1 (treated with $14 \mu \mathrm{l}$ of ethidium bromide solution associated with normal saline injected to the lateral ventricle by gavage) and experimental 2, experimental 3 and experimental 4 groups (treated intravenously with $14 \mu \mathrm{l}$ of ethidium bromide solution with 300, 600 and $1200 \mathrm{mg} / \mathrm{kg}$ doses of the Aloe vera alcoholic extract gel by gavage, respectively ) $(4,21,22)$. All the injections were performed during 35 days and blood samples were then taken from the hearts for measuring serum levels of TGF- $\beta$, interleukin 1 and interferon gamma (IFN $\gamma$ ). ELISA test was used to measure 
Table 1: Amount of the biochemical parameters in the various groups (Mean \pm SEM)

\begin{tabular}{|c|c|c|c|c|c|c|}
\hline & & & & Ethidium bromide $+\mathbf{3 0 0}$ & Ethidium bromide +600 & Ethidium bromide +1200 \\
\hline Parameters & Control & Sham & Ethidium bromide & $\begin{array}{c}\mathrm{mg} / \mathrm{kg} \text { Aloe vera alcoholic } \\
\text { extract gel }\end{array}$ & $\begin{array}{c}\mathrm{mg} / \mathrm{kg} \text { Aloe vera alcoholic } \\
\text { extract gel }\end{array}$ & $\begin{array}{c}\mathrm{mg} / \mathrm{kg} \text { Aloe vera alcoholic } \\
\text { extract gel }\end{array}$ \\
\hline $\begin{array}{l}\text { TGF- } \beta \\
(\mathrm{Pg} / \mathrm{ml}) \\
\end{array}$ & $59.4 \pm 4.6$ & $64.6 \pm 9.1$ & $127.6 \pm 6.6^{\star \star}$ & $124 \pm 3.8 c^{\star *}$ & $116.4 \pm 4.15 b^{\star \star}$ & $103.6 \pm 13.6^{\star \star *}$ \\
\hline Interleukin 1 & $659.8 \pm 69.2$ & $660.1 \pm 69.06$ & $1013.04 \pm 10.96^{\star \star}$ & $955.6 \pm 35.2^{\text {**\# }}$ & $879.5 \pm 51.12^{\#}$ & $770.7 \pm 52.02^{\# \#}$ \\
\hline $\begin{array}{l}\text { Interferon } \\
\text { gamma }\end{array}$ & $37.94 \pm 4.6$ & $39.54 \pm 9.1$ & $53.94 \pm 6.6^{*}$ & $53.14 \pm 3.8^{*}$ & $52.72 \pm 4.15 b^{*}$ & $47.90 \pm 13.6^{*}$ \\
\hline
\end{tabular}

** - Indicates a significant difference at level of $P \leq 0.01$ compared to the control group

* - Indicates a significant difference at level of $P \leq 0.05$ compared to the control group.

\#\# - Indicates a significant difference at level of $P \leq 0.01$ compared to the group treated with ethidium bromide alone.

\# - Indicates a significant difference at level of $\mathrm{P} \leq 0.05$ compared to the group treated with ethidium bromide alone.

the mentioned factors. The obtained data were analyzed using SPSS version 21 and analyzed by Analysis of Variance (ANOVA) test and Duncan test. The $\mathrm{P}<0.05$ is considered as a significant difference.

\section{RESULTS}

\section{Biochemical Results}

The results of this study showed that serum levels of TGF- $\beta$, interleukin 1 and interferon gamma in the group treated with ethidium bromide were significantly increased at the significance level of $\mathrm{P} \leq 0.05$ compared to the control group. The levels of TGF- $\beta$, interleukin 1 and interferon gamma were not significantly altered in the rats concurrently received ethidium bromide associated with $300 \mathrm{mg} / \mathrm{kg}$ Aloe vera alcoholic extract gel compared to the group received ethidium bromide alone. In addition, no significant changes in the mean serum concentrations of TGF- $\beta$ and interferon gamma of the rats concurrently received ethidium bromide with $600 \mathrm{mg} / \mathrm{kg}$ Aloe vera alcoholic extract gel was observed compared to those treated with ethidium bromide alone, but the mean serum concentration of interleukin 1 in this group showed a significant reduction at the level of $\mathrm{P}<0.05$ compared to the group treated with ethidium bromide alone. The results of data analysis in this study showed that serum levels of TGF- $\beta$, interleukin 1 and interferon gamma in the rats concurrently received ethidium bromide associated with $1200 \mathrm{mg} / \mathrm{kg}$ dose of the extract were significantly reduced at the level of $\mathrm{P} \leq 0.05$ compared to those treated with ethidium bromide alone (Table 1).

\section{DISCUSSION AND CONCLUSION}

Ethidium bromide is widely used as a DNA inserter to induce toxic demyelination in rodents (23). Various studies have shown that direct injection of the gliotoxin ethidium bromide induces oxidative stress and increases malondialdehyde (MDA) as index of lipid peroxidation, which indicates increased production of free radicals in the central nervous system (24).

The results of this study showed that ethidium bromide increases the serum levels of the inflammatory factors including, TGF- $\beta$, interleukin- 1 and interferon gamma (IFN- $\gamma$ ). Studies have suggested that TGF- $\beta$ has several functions that include cell differentiation as well as inhibition of cell growth, modulation and suppression of inflammatory and immune responses which contribute to the process of inflammation in multiple sclerosis $(25,26)$. Other studies have suggested that cortisol is one of the indicators that suppresses the immune system during inflammation process and so triggers immune deficiency of the body. This hormone acts by reducing the production of lymphocytes, especially $T$ lymphocytes, by reducing the migration of white blood cells to the inflamed area, and also by reducing the release of interleukin-1 from white blood cells (27). In relation to the role of interleukins in MS disease, other studies have suggested that IL- 6 and IL-17 have an important role in the disease (28). Results of other studies have also indicated that MS progress is related to IFN- $\gamma$ signaling. Among the biological activities of IFN- $\gamma$, activation of macrophages is of considerable importance. Based on this, IFN- $\gamma$ leads to upregulation of pre-inflammatory parameters such as IL-12, IL15 and TNF- $\alpha$. Excessive release of IFN- $\gamma$ is associated with pathogenesis of autoimmune and chronic inflammatory diseases. This cytokine stimulates major inflammatory factors, such as IL-18 and TNF- $\alpha$, and thus contributes in the onset of multiple sclerosis (29).

In the present study, the levels of inflammatory factors of TGF- $\beta$, interleukin- 1 and interferon gamma reduced dosedependently by the Aloe vera alcoholic extract gel compared to those of the ethidium bromide group. Studies have shown that Aloe vera extract containing polysaccharides, polyphenols, and vitamins A, C and E has antioxidant properties in humans and animals $(30,31,32)$. According to results of these studies, Aloe vera extract gel can trap free radicals or 
remove free radicals through a series of bonding reactions along with antioxidant enzymes $(30,31)$. Studies have also shown that Aloe vera has anti-inflammatory properties and it is effective in the treatment of inflammatory diseases and wound healing $(18,17)$. Therefore, it is probable in the present study that the Aloe vera extract gel with anti-oxidant and anti-inflammatory properties prevented the effect of ethidium bromide on enhancement of serum levels of the inflammatory factors. The results of studies have shown that Aloe vera is effective on inhibiting inflammatory responses by inhibiting the production of interleukin 6 and interleukin 8, decreasing the adhesion of leukocytes, increasing interleukin 10 levels, and decreasing tumor necrosis factor alpha levels (TNF $\alpha)(17,18)$. Aloe vera plant improves and reduces TNF a levels in animal models with multiple sclerosis and thus improves symptoms in these patients, which shows that Aloe vera extract is an excellent complement in improvement of symptoms in such individuals (33).

\section{TOTAL CONCLUSION}

According to the results of this study, it was found that ethidium bromide which induced multiple sclerosis in the experimental model of the rats could increase the serum levels of TGF- $\beta$, interleukin- 1 and interferon gamma, while the Aloe vera extract gel is dose dependent and probably due to its antioxidant and anti-inflammatory properties, it decreased the serum levels of the inflammatory factors including, TGF- $\beta$, interleukin- 1 and interferon gamma in the rats infected with ethidium bromide-induced MS disease.

\section{REFERENCES}

1. Sluder JA. Newhouse P, Fain D. Pediatric and adolescent multiple sclerosis. Adolescent Medicine Clinics. 2002;13(3):461.

2. Kasper D, Braunwald E, Fauci A, Hauser S, Longo D, Jameson J, et al. Harrison's principles of internal medicine. 16th ed. New York: McGraw-Hill Medical Publishing. 2005.

3. Orton SM, Herrera BM, Yee IM, Valdar W, Ramagopalan SV, Sadovnick AD, Canadian Collaborative Study Group. Sex ratio of multiple sclerosis in Canada: a longitudinal study. The Lancet Neurology. 2006;5(11):932-936. https://doi.org/10.1016/S1474-4422(06)70581-6

4. Nabavi SM, Sh P, Ghassemi H. Clinical Course and prognosis of 203 patients with MS in shahid Mostafa Khomeini Hospital, Tehran 2002. Tehran University Medical Journal TUMS Publications. 2006;64(7):90-97.

5. Smith $M M$, Arnett PA. Factors related to employment status changes in individuals with multiple sclerosis. Multiple Sclerosis Journal. 2005;11(5):602-609. https://doi.org/10.1191/1352458505ms1204oa PMid:16193900

6. Compston A, Coles A. Multiple sclerosis. The Lancet. 2008;372(9648):1502-17. https://doi.org/10.1016/S01406736(08)61620-7

7. Castellano V, Patel DI, White L. Cytokine responses to acute and chronic exercise in multiple sclerosis. Journal of Applied Physiology. 2008;104(6):1697-1702. https://doi.org/10.1152/japplphysiol.00954.2007 PMid:18388249

8. Taylor and Francis. Hand book of multiple sclerosis. Cook SD, editions. Managing the Symptoms of Multiple Sclerosis. 4 th ed. New York. 2006;265-71.

9. Link J, Söderström $M$, Olsson $T$, Höjeberg $B$, Ljungdahl $\AA$, Link H. Increased transforming growth factor- $\beta$, interleukin-4, and interferon- $\gamma$ in multiple sclerosis. Annals of neurology. 1994;36(3):379-386. https://doi.org/10.1002/ana.410360309 PMid:8080246

10. Ferrero $S$, Pretta $S$, Ragni N. Multiple sclerosis: management issues during pregnancy. European Journal of Obstetrics and Gynecology and Reproductive Biology. 2004;115(1):3-9. https://doi.org/10.1016/j.ejogrb.2003.10.020 PMid:15223156

11. Apel-Neu A, Zettl UK. Complementary and alternative medicine in multiple sclerosis. J Neurol. 2008;255 Suppl 6:82-6. https://doi.org/10.1007/s00415-008-6015-9 PMid:19300965

12. Goudarzvand M, Javan M, Mirnajafi-ZadehJ, Mozafari S, Tiraihi T. Vitamins E and D3 attenuate demyelination and potentiate remyelination processes of hippocampal formation of rats following local injection of ethidium bromide. Cell Mol Neurobiol. 2010;30:289-299. https://doi.org/10.1007/s10571-009-9451-x PMid:19768531

13. Telefo PB, Moundipa PF, Tchouanguep FM. Oestrogenicity and effect on hepatic metabolism of the aqueous extract of the leaf mixture of Aloe buettneri, Dicliptera verticillata, Hibiscus macranthus and Justicia insularis. Fitoterapia. 2002;73(6):472-478. https://doi.org/10.1016/S0367-326X(02)00177-6

14. Oketch-Rabah HAT. Leaf compounds in potential plantation species of Aloe in Kenya. Journal of herbs, spices and medicinal plants. 1997;4(3):25-33. https://doi.org/10.1300/J044v04n03_04 
15. Saks Y, Barkai-Golan R. Aloe vera gel activity against plant pathogenic fungi. Postharvest Biology and Technology. 1995;6(1-2):159-165. https://doi.org/10.1016/0925-5214(94)00051-S

16. Rajasekaran S, Sivagnanam K, Subramanian S. Antioxidant effect of Aloe vera gel extract in streptozotocininduced diabetes in rats. Pharmacol Rep. 2005;57(1):90-6. PMid:15849382

17. Eamlamnam K, Patumraj S, Visedopas N, Thong-Ngam D. Effects of Aloe vera and sucralfate on gastric microcirculatory changes, cytokine levels and gastric ulcer healing in rats. World journal of gastroenterology. 2006;12(13):2034. https://doi.org/10.3748/wjg.v12.i13.2034 PMid:16610053 PMCid:PMC4087681

18. Boudreau MD, Frederick $A B$. An evaluation of the biological and toxicological properties of Aloe barbadensis (miller), Aloe vera. Journal of Environmental Science and Health. 2006;24(1):103-154. https://doi.org/10.1080/10590500600614303 PMid:16690538

19. Loots dT, van der Westhuizen FH, Botes L. Aloe ferox leaf gel phytochemical content, antioxidant capacity, and possible health benefits. J Agric Food Chem. 2007;55(17):6891-6. https://doi.org/10.1021/jf071110t PMid: 17661490

20. Lim BO, Seong NS, Choue RW, Kim JD, Lee HY, Kim SY, et al. Efficacy of dietary aloe vera supplementation on hepatic cholesterol and oxidative status in aged rats. J Nutr Sci Vitaminol (Tokyo). 2003;49(4):292-6. https://doi.org/10.3177/jnsv.49.292

21. Mehrabian S, Majd A, Jonoubi $P$, Kheiri A. A study of the antimutagenic effects of different extracts of Aloe vera leaf gel and latex using Ames test. Arak Medical University Journal (AMUJ). 2012;15(61):100-106.

22. Jafarzadeh $\mathrm{H}$, Arabi $M$, Najafi $N$, Ahadi AM. Effect of Aloe vera gel on TGF- $\beta$ gene expression in incisional skin wound in BALB/c mice. J Gorgan Univ Med Sci. 2014;16 (3):16-23.

23. Abdel-Salam OME, Khadrawy YA, Salem NA, Sleem AA. Oxidative stress in a model of toxic demyelination in rat brain: the effect of piracetam and vinpocetine. Neurochem Res. 2011;36:1062-1072. https://doi.org/10.1007/s11064-011-0450-1 PMid:21448596

24. Abdel-Salam OME, Khadrawy YA, Mohammed NA, Youness ER. The effect of gabapentin on oxidative stress in a model of toxic demyelination in rat brain. J Basic Clin Physiol Pharmacol. 2012;23:61-68. https://doi.org/10.1515/jbcpp-2012-0004 PMid:23089532

25. Abbas AK, Litchman Ah, Pilai S. Cellular and molecular immunology. 7th ed. Philadelphia, PA, Elsevier Saunders. 545. (Student Consult). 2012.

26. Kumar V, Abbas Ak, Fausto N, Mitchell R. (eds).Tissuerepair:regenera on, healingand fibrosis. Robin's basic pathology. Philadelphia: Saunders. 2007:63-5.

27. Guyton A, Hall J. Medical physiology. Translated by Shadan F. Tehran. Tchehr Co. 2006:1480-92.

28. Mix E, Meyer-Rienecker $\mathrm{H}$, Hartung HP, Zettl UK. Animal models of multiple sclerosis-Potentials and limitations. Prog Neurobiol. 2010;92(3):386-404. https://doi.org/10.1016/j.pneurobio.2010.06.005 PMid:20558237

29. Chen J, Liu X. The role of interferon $\gamma$ in regulation of CD4+ T-cells and its clinical implications. Cellular Immunology. 2009;254(2):85-90. https://doi.org/10.1016/j.cellimm.2008.09.001 PMid:18848698

30. Loots dT, van der Westhuizen FH, Botes L. Aloe ferox leaf gel phytochemical content, antioxidant capacity, and possible health benefits. J Agric Food Chem. 2007;55(17):6891-6. https://doi.org/10.1021/jf071110t PMid: 17661490

31. Lim BO, Seong NS, Choue RW, Kim JD, Lee HY, Kim SY, et al. Efficacy of dietary aloe vera supplementation on hepatic cholesterol and oxidative status in aged rats. J Nutr Sci Vitaminol (Tokyo). 2003;49(4):292-6. https://doi.org/10.3177/jnsv.49.292

32. Mehrabian S, Majd A, Jonoubi P, Kheiri A. A study of the antimutagenic effects of different extracts of Aloe vera leaf gel and latex using Ames test. Arak Medical University Journal (AMUJ). 2012;15(61):100-106.

33. Mosayebi G, Ghazavi A, Aghili B, Mirshafie A. Immunomodulating activity of Aloe vera in animal model of multiple sclerosis. Arak Medical University Journal (AMUJ). 2009;12(3):109-115.

$\diamond \diamond \diamond \diamond \diamond \diamond \diamond$

http://www.ejgm.co.uk 